\title{
Analysis path coefficient of yield earliness traits in wheat (Triticum aestivum L.)
}

\author{
Asghar Ali Rajper ${ }^{1}$, Shahla Karim Baloch ${ }^{2 *}$, Kashmala Baloch ${ }^{3}$, \\ Saeed Ahmed ${ }^{1}$, Arshad Ali Kaleri ${ }^{1}$, Abdul Latif Leghari ${ }^{1}$, Sajid \\ Hussain Kaleri ${ }^{3}$, Jay Kumar Soothar ${ }^{4}$, Salman Raza Soomro ${ }^{1}$ and \\ Rameez Raja Kaleri ${ }^{5}$ \\ 1. Department of Plant Breeding and Genetics, Sindh Agriculture University, Tandojam-Pakistan \\ 2. Department of Biotechnology, Sindh Agriculture University, Tandojam-Pakistan \\ 3. Information Technology Centre, Sindh Agriculture University, Tandojam-Pakistan \\ 4. Department of Soil Sciences, Sindh Agriculture University, Tandojam-Pakistan \\ 5. Department of Animal Breeding and Genetics Sindh Agriculture University, Tandojam-Pakistan \\ *Corresponding author's email: shahlabaloch@gmail.com
}

Citation

Asghar Ali Rajper, Shahla Karim Baloch, Kashmala Baloch, Saeed Ahmed, Arshad Ali Kaleri, Abdul Latif Leghari, Sajid Hussain Kaleri, Jay Kumar Soothar, Salman Raza Soomro and Rameez Raja Kaleri. Analysis path coefficient of yield earliness traits in wheat (Triticum aestivum L.). Pure and Applied Biology. Vol. 7, Issue 1, pp112-120. http://dx.doi.org/10.19045/bspab.2018.70014

\begin{tabular}{llll}
\hline \hline Received: 16/10/2017 & Revised: 29/12/2017 & Accepted: 05/01/2018 & Online First: 10/01/2018 \\
\hline
\end{tabular}

\section{Abstract}

The current investigation was carried out to analyse the coefficient and partitioning of direct and direct effect of yield component and earliness traits in the genotypes of wheat. Current research was conducted at experimental area of Southern Wheat Station Tandojam, during the year 2014-15 in (RCBD) Randomized block design having 3 replications. The total 8 genotypes of wheat viz., Sarang, NIA amber, TD ${ }^{-1}$, Benazir, Soghat, Anmol, Imdad-05 and Kiran-95 were used to examine correlation and path analysis. Nine traits, namely, days to $75 \%$ heading, days to $75 \%$ maturity, height of plant ${ }^{-1}$, plant1 tillers, length of spikes, yield of gain plant ${ }^{-1}$, spikelets spike ${ }^{-1}$, seed index and gains spikes ${ }^{-1}$ were recorded. Analysis of variance was found significantly different among the traits of genotypes of current research. Mean performance based on the variety $\mathrm{TD}^{-1}$ was showed better production in the term days of $(75 \%)$ heading days and maturity $(75 \%)$, number of seed index and spike ${ }^{-1}$ spikelet's. Whereas the variety Anmol was found best result in all tiller plants ${ }^{-1}$ number, grain spike ${ }^{-1}$ quantity and all yield grain plant $^{-1}$, therefore mention verities may because favourable for hybridization to produce new wheat promising verities. The results for phenotypic correlation showed seed index and tiller plant- 1 were positive and high correlated with grain yield plant $^{-1}$, hence components of yield can be consider as selective tool for bringing progress in wheat grain production of this crop. Analysis of path coefficient showed the direct effect of grain plant ${ }^{-1}$ yield was quickly found by the spikep ${ }^{-1}$ grains 0.8320 followed by index of seed 0.1886 , whereas the result of spikelet's spike-1 was observed positively influence on the yield of grain. In controversial the highest negatively influence was observed by plant-1 tillers number 0.3702 , followed by the height of plant 0.0836 and length of spike 0.3813 that is why, direction genotypes selection for the yield of grain because of spikelet's spike-1, index of seed and grains of spike $^{-1}$.

Keywords: Analysis; Earliness traits; Path coefficient; Wheat; Yield

\section{Introduction}

Wheat (Triticum aestivum L.) belongs to family Poaceae. Worldwide it is consumed as prime and staple food. The origin of wheat is Fertile Crescent which is an area of south west Asia. In Pakistan cultivation of wheat was 
carried out more than 5000 years ago, of that evidences were obtained from Mohan-Jodaro. There are major fifteen known species within Triticum genus [1], in which near about $90 \%$ of whole world's production of wheat is obtained from three species: Triticum aestivum (common wheat), Triticum durum (durum or macaroni wheat) and Triticum compactum (club wheat). In Pakistan wheat is major leading crop, grown over wide range of environments. The continuous increase in production of wheat could be attributed for evolution of different modern technologies along with potentially high yielding varieties of wheat in. Variability analysis of different traits and presence of specific character with another trait contributing to the crop yield and that would be first priority for successful breeding program [2]. In genotypes of wheat the genetic variability can be estimated on the quantitative traits based. For successful breeding programme selection of parents is very importance. Wheat based on required information, magnitude and nature of variation among the population and the association of different character having yield and in between themselves and effect of environmental conditions on the expression of necessary characters [3]. The path coefficient analysis quantifies inter-relationship of various components of yield and also indicates that whether the effect is reflected directly to the yield or it can take another path ways to make an effect. In different crops path analysis was used to determine the direct and indirect influence on different yield components. [3, 4]. Yield of wheat fluctuates with the environmental and genetical interaction due to yield of grain is an essential quantities parameter that is productivity by various influenced component factors which affect indirectly or directly on the yield of grain. The production of wheat can be enhanced through the development of latest varieties which must be productive and can be grows on different stresses and agro-climatic conditions. Selection for the improvement in grain yield can only be most effective when the genetic material displayed the variability is present [4-6]. Therefore current experiment was performed for characterization for best famous wheat genotypes for observation early maturity and also to determine the association among different yield traits.

\section{Materials and methods}

Total field work was conducted at experimental area of Southern Wheat Station Tandojam, during the year 2014-15, to observe correlation path analysis and coefficient of yield and earliness traits of 8 various genotypes of wheat (Triticum aestivum L) viz., Sarang, NIA amber, TD-1, Benazir, Soghat, Anmol-91, Imdad-05 and Kiran-95. The seed was sown with three replications in RCBD Randomized complete block design.

In this investigation the data was collected from $75 \%$ days heading to $75 \%$ days of maturity, tillers plant-1, length of spike- $1 \mathrm{~cm}$, height of plant $\mathrm{cm}$, index of seed 100 grain weight in gram, yield of grain plant-1 and spike-1 of grain $g$

\section{Statistical analysis}

Collected data was placed for to the analysis of variance according to [7], correlation coefficient was determined after [8] and path coefficient analysis was performed after [9].

\section{Results}

Current investigating was performed to find out the correlation coefficient and analysis of path way of different earliness as well as morphological traits linked to the production of wheat crop, during the year of 2014-2015. Investigation was carried out on the experimental station of Wheat research station southern field, Tandojam, for observing the days $75 \%$ to $75 \%$ maturity days, plant tillers, index of seed, height of plant, spike-1 length, spikelts spike $=1$, spikes $=1 \mathrm{f}$ grains and grain yield of plant -1 for 8 promising wheat varieties.

\section{Analysis of variance}

The variance analysis for each character has been presented in (Table 1) that showed significant difference among the genotypes at the level of $\mathrm{P} \leq 0.01$ for each traits that is showed the presence of genetic variation among the genotypes of study for more assessment. 
Table 1. Mean square from the variance analysis for yield related morphological and earliness traits for wheat bread (Triticum aestivum $\mathbf{L}$.)

\begin{tabular}{|c|c|c|c|}
\hline \multirow{2}{*}{ Traits } & \multicolumn{3}{|c|}{ Mean square } \\
\cline { 2 - 4 } & $\begin{array}{c}\text { Replications } \\
\text { D.F.2 }\end{array}$ & $\begin{array}{c}\text { Verities } \\
\text { D.F.7 }\end{array}$ & $\begin{array}{c}\text { Error } \\
\text { D.F.14 }\end{array}$ \\
\hline Days to 75\% heading & 0.035 & $109.748^{* *}$ & 0.265 \\
\hline Days to 75\% maturity & 0.5717 & $70.4855^{* *}$ & 0.3926 \\
\hline Plant height & 7.432 & $180.556^{* *}$ & 10.041 \\
\hline No. of tillers plant-1 & 0.11167 & $2.15595^{* *}$ & 0.1459 \\
\hline Spike length & 0.07167 & $2.69619^{* *}$ & 0.1569 \\
\hline Spikeltets spikes-1 & 0.06000 & $1.82762^{* *}$ & 0.2047 \\
\hline Grains spikes-1 & 461.895 & $253.623^{* *}$ & 70.278 \\
\hline Seed index & 0.7776 & $35.5456^{* *}$ & 0.7978 \\
\hline Grain yield plant-1 & 0.7817 & $11.9026^{* *}$ & 0.2540 \\
\hline \multirow{2}{*}{.* }
\end{tabular}

\section{$* *=$ Significant at $1 \%$ probability level}

\section{Genotypes mean performance}

Data displayed in the (Table 2) exhibited that TD-1 took minimum days to heading (62.53), minimum days to maturity (107.86) and showed dwarf plants $(72.46 \mathrm{~cm})$ with highest

\section{seed index $(50.20 \mathrm{~g})$. Variety Anmol \\ Table 2. Mean perform respectively.}

displayed higher number of tillers (6.13 high plant-1 yield grain (13.73) and high spike-1 grains (59.0), whereas Kiran-95 and Imdad05 showed higher spike length $(12.33 \mathrm{~cm})$ and higher spikelets spike $^{-1}(19.66 \mathrm{~cm})$

\begin{tabular}{|c|c|c|c|c|c|c|c|c|c|}
\hline \multirow{2}{*}{ Characters } & \multicolumn{9}{|c|}{ Varieties } \\
\cline { 2 - 11 } & Sarang & $\begin{array}{c}\text { NIA } \\
\text { Amber }\end{array}$ & TD-1 & Benazir & Soghat & Anmol & $\begin{array}{c}\text { Imdad- } \\
\mathbf{0 5}\end{array}$ & $\begin{array}{c}\text { Kiran- } \\
\mathbf{9 5}\end{array}$ & $\begin{array}{c}\text { L.S.D. } \\
(\mathbf{5 \% )}\end{array}$ \\
\hline $\begin{array}{c}\text { Days to 75\% } \\
\text { heading }\end{array}$ & 77.53 & 81.13 & 62.53 & 69.66 & 70.06 & 70.53 & 69.93 & 78.20 & 0.90 \\
\hline $\begin{array}{c}\text { Days to 75\% } \\
\text { maturity }\end{array}$ & 119.53 & 117.4 & 107.86 & 110.20 & 117.86 & 118.06 & 120.13 & 121.26 & 1.09 \\
\hline Plant height (cm) & 98.53 & 93.93 & 72.46 & 89.06 & 86.33 & 91.40 & 93.80 & 91.33 & 5.54 \\
\hline No. of tillers plant- & 4.20 & 4.60 & 5.60 & 3.66 & 4.86 & 6.13 & 5.66 & 5.60 & 0.66 \\
\hline Spike length (cm) & 10.06 & 10.60 & 10.46 & 10.13 & 9.26 & 10.90 & 11.56 & 12.33 & 0.69 \\
\hline Spikelets spike-1 & 19.00 & 18.60 & 19.40 & 17.66 & 17.40 & 18.73 & 19.66 & 18.73 & 0.79 \\
\hline Grains spike-1 & 45.00 & 44.26 & 39.33 & 47.86 & 47.53 & 59.40 & 58.13 & 52.80 & 7.68 \\
\hline Seed index (g) & 44.68 & 38.80 & 50.20 & 46.64 & 45.61 & 45.74 & 44.76 & 42.13 & 1.56 \\
\hline Grain yield plant (g) & 9.26 & 8.46 & 12.60 & 7.33 & 7.86 & 13.73 & 10.66 & 9.4 & 0.88 \\
\hline
\end{tabular}

\section{Path coefficient analysis}

Moreover knowledge about the association among the yield of grain and many component of production were observed through the procedure of analysis of path coefficient variance of phenotypic correlation. Analysis of path coefficient showed key point regarding the share of various productive traits to all yield of grain in different wheat genotypes under the present research. It can also provide an effective way to find out the both direct and indirect sources of correlation. Indirect and direct influence of these various components will be expressed on yield of grain and its contribution ration described in (Table 3). Various components of yield like $75 \%$ days heading, $75 \%$ days of maturity, plant tillers, number of grain spike1, index of seed 1000 grain weight, length of spikes, spike-1 of spikelet's, are said to be independent variable on the procedure of path analysis was implemented to observe the influence and share percentage of mention different component on the plant grain yield that is known as dependent variable. The direct and highest influence of plant-1 grain 
yield was added frequently through spike ${ }^{-1}$ grains $(0.8320)$ than by days to $75 \%$ maturity (0412) which contribute 84.29 and $144.04 \%$ respectively. The highest positive effect of days to $75 \%$ heading via spike length (0.5912) which constitute $67.66 \%$ of the phenotypic correlation followed by the sipkelets spike-1
(0.5902) via tillers plant-1, whereas highest negative effect of seed index (-0.826) via days to $75 \%$ maturity constitute $288.811 \%$ of the total phenotypic correlation. Further (Table 4) displayed that highly significant correlation between grain yield plant ${ }^{-1}$ is 0.987 and with spike length is 0.8737 .

Table 3. The alternate pathway and direction effect of the days heading $75 \%$ maturity days $75 \%$ spike of spikelets, plant height, index of seed, length of spikes and spikelet's spike on the grain of what

\begin{tabular}{|c|c|c|c|c|c|}
\hline The Characteristics & $\begin{array}{c}\text { Direct } \\
\text { influence }\end{array}$ & $\%$ & $\begin{array}{l}\text { Alternate } \\
\text { Influence }\end{array}$ & $\%$ & ( $\mathbf{R})$ \\
\hline Direct effect & - & - & - & - & - \\
\hline 1.Days to $75 \%$ heading & 0.0259 & 16.961 & - & - & - \\
\hline Alternate pathways & - & - & - & - & - \\
\hline Days to $75 \%$ maturity & - & - & -0.0096 & 6.286 & - \\
\hline Plant height & - & - & 0.0416 & 27.242 & - \\
\hline Tillers plant $^{-1}$ & - & - & -0.0151 & 9.888 & \\
\hline Spike length & - & - & -0.0910 & 59.593 & \\
\hline Spikelets spike $^{-1}$ & - & - & -0.0145 & 9.495 & - \\
\hline Grains spike $^{-1}$ & - & - & -0.0720 & 47.151 & - \\
\hline Seed index & - & - & -0.0180 & 11.787 & - \\
\hline Total effects & - & - & - & - & $-0.1527^{\mathrm{ns}}$ \\
\hline Direct effect & - & - & - & - & - \\
\hline 2.Days to75 \% Maturity & 0.4120 & 144.055 & - & - & - \\
\hline Alternate pathways & - & - & - & - & - \\
\hline Days to $75 \%$ heading & - & - & 0.5680 & 198.601 & - \\
\hline Plant height & - & - & -0.3610 & 126.223 & - \\
\hline Tillers plant $^{-1}$ & - & - & 0.4680 & 163.636 & - \\
\hline Spike length & - & - & -0.7660 & 267.832 & - \\
\hline Spikelets spike $^{-1}$ & - & - & 0.3470 & 121.328 & - \\
\hline Grains spike $^{-1}$ & - & - & 0.4440 & 155.244 & - \\
\hline Seed index & - & - & -0.8260 & 288.811 & - \\
\hline Total effects & - & - & - & - & $0.286^{\mathrm{ns}}$ \\
\hline Direct effect & - & - & - & - & - \\
\hline 3.Plant height & 0.0836 & 100.722 & - & - & - \\
\hline Alternate pathways & - & - & - & - & - \\
\hline Days to $75 \%$ heading & - & - & 0.0405 & 48.795 & - \\
\hline Days to $75 \%$ maturity & - & - & -0.0409 & 49.277 & - \\
\hline Tillers plant $^{-1}$ & - & - & 0.0416 & 50.120 & - \\
\hline Spike length & - & - & -0.0447 & 53.855 & - \\
\hline Spikelets spike $^{-1}$ & - & - & 0.0559 & 67.349 & - \\
\hline Grains spike $^{-1}$ & - & - & -0.0468 & 56.385 & - \\
\hline Seed index & - & - & -0.0062 & 7.469 & - \\
\hline Total effects & - & - & - & - & $0.083^{\mathrm{ns}}$ \\
\hline Direct effect & - & - & - & - & - \\
\hline 4.Tillers plant ${ }^{-1}$ & 0.3702 & 45.146 & - & - & - \\
\hline Alternate pathways & - & - & - & - & - \\
\hline Days to $75 \%$ heading & - & - & 0.1602 & 19.536 & - \\
\hline Days to $75 \%$ maturity & - & - & -0.3928 & 47.902 & - \\
\hline Plant height & - & - & 0.3803 & 46.378 & - \\
\hline Spike length & - & - & -0.4076 & 49.707 & - \\
\hline
\end{tabular}




\begin{tabular}{|c|c|c|c|c|c|}
\hline Spikelets spike $^{-1}$ & - & - & 0.5902 & 71.975 & - \\
\hline Grains spike $^{-1}$ & - & - & 0.4404 & 53.707 & - \\
\hline Seed index & - & - & -0.3202 & 39.048 & - \\
\hline Total effects & - & - & - & - & $0.820^{*}$ \\
\hline Direct effect & - & - & - & - & - \\
\hline 5.Spike length & 0.3813 & 43.641 & - & - & - \\
\hline Alternate pathways & - & - & - & - & - \\
\hline Days to $75 \%$ heading & - & - & 0.5912 & 67.666 & - \\
\hline Days to $75 \%$ maturity & - & - & -0.3076 & 35.206 & - \\
\hline Plant height & - & - & 0.1602 & 18.335 & - \\
\hline Tillers plant ${ }^{-1}$ & - & - & -0.3202 & 36.648 & - \\
\hline Spikelets spike $^{-1}$ & - & - & 0.3712 & 42.485 & - \\
\hline Grains spike $^{-1}$ & - & - & -0.4928 & 56.403 & - \\
\hline Seed index & - & - & 0.4904 & 56.129 & - \\
\hline Total effects & - & - & - & - & $0.8737^{\text {*** }}$ \\
\hline Direct effect & - & - & - & - & - \\
\hline 6.Spikelets spike ${ }^{-1}$ & 0.1612 & 19.810 & - & - & - \\
\hline Alternate pathways & - & - & - & - & - \\
\hline Days to $75 \%$ heading & - & - & 0.3712 & 45.618 & - \\
\hline Days to $75 \%$ maturity & - & - & -0.4828 & 59.333 & - \\
\hline Plant height & - & - & 0.3813 & 46.860 & - \\
\hline Tillers plant $^{-1}$ & - & - & -0.3076 & 37.802 & - \\
\hline Spike length & - & - & -0.3202 & 39.351 & - \\
\hline Grains spike $^{-1}$ & - & - & 0.5702 & 70.074 & - \\
\hline Seed index & - & - & 0.4404 & 54.123 & - \\
\hline Total effects & - & - & - & - & $0.8137^{*}$ \\
\hline Direct effect & - & - & - & - & - \\
\hline 7.Grains spike ${ }^{-1}$ & 0.8320 & 84.295 & - & - & \\
\hline Alternate pathways & - & - & - & - & - \\
\hline Days to $75 \%$ heading & - & - & 0.5470 & 55.420 & - \\
\hline Days to $75 \%$ maturity & - & - & 0.0630 & 6.382 & - \\
\hline Plant height & - & - & -0.4770 & 48.328 & - \\
\hline Tillers plant $^{-1}$ & - & - & 0.4370 & 44.275 & - \\
\hline Spike length & - & - & -0.1880 & 19.047 & - \\
\hline Spikelets spike $^{-1}$ & - & - & 0.4410 & 44.680 & \\
\hline Seed index & - & - & -0.6680 & 67.679 & - \\
\hline Total effects & - & - & - & - & $0.987^{* *}$ \\
\hline Direct effect & - & - & - & - & - \\
\hline 8.Seed index & 0.1886 & 25.698 & - & - & - \\
\hline Alternate pathways & - & - & - & - & - \\
\hline Days to $75 \%$ heading & - & - & 0.2818 & 38.397 & - \\
\hline Days to $75 \%$ maturity & - & - & -0.0429 & 5.845 & - \\
\hline Plant height & - & - & 0.1766 & 24.063 & - \\
\hline Tillers plant ${ }^{-1}$ & - & - & -0.0844 & 11.500 & - \\
\hline Spike length & - & - & 0.1575 & 21.460 & - \\
\hline Spikelets spike $^{-1}$ & - & - & -0.0821 & 11.186 & - \\
\hline Grains spike $^{-1}$ & - & - & 0.1388 & 18.912 & - \\
\hline Total effects & - & - & - & - & $0.7339^{*}$ \\
\hline 9.Residual effect & - & - & - & - & 0.1396 \\
\hline
\end{tabular}


Table 4. Correlation coefficient ( $r$ ) and its significance for various character combinations

\begin{tabular}{|c|c|}
\hline Character association & Correlation coefficient ( $r)$ \\
\hline 1. Days to $75 \%$ heading vs days to $75 \%$ maturity & $0.834 * *$ \\
\hline 2. Days to $75 \%$ heading vs plant height & $-0.779 * *$ \\
\hline 3. Days to $75 \%$ heading vs tillers plant ${ }^{-1}$ & $0.734 *$ \\
\hline 4. Days to $75 \%$ heading vs spike length & $-0.874 * *$ \\
\hline 5. Days to $75 \%$ heading vs spikelets spike ${ }^{-1}$ & $-0.752 *$ \\
\hline 6. Days to $75 \%$ heading vs grains spike ${ }^{-1}$ & $-0.115 \mathrm{~ns}$ \\
\hline 7. Days to $75 \%$ heading vs seed index & $-0.851^{* *}$ \\
\hline 8. Days to $75 \%$ heading vs grains yield plant $^{-1}$ & $-0.152 \mathrm{~ns}$ \\
\hline 9. Days to $75 \%$ maturity vs plant height & $0.780 * *$ \\
\hline 10. Days to $75 \%$ maturity vs tillers plant ${ }^{-1}$ & $0.254 \mathrm{~ns}$ \\
\hline 11. Days to $75 \%$ maturity vs spike length & $0.401 \mathrm{~ns}$ \\
\hline 12. Days to $75 \%$ maturity vs spikelets spike ${ }^{-1}$ & $0.121 \mathrm{~ns}$ \\
\hline 13. Days to $75 \%$ maturity vs grains spike ${ }^{-1}$ & $0.326 \mathrm{~ns}$ \\
\hline 14. Days to $75 \%$ maturity vs seed index & $-0.713^{*}$ \\
\hline 15. Days to $75 \%$ maturity vs grains yield plant $^{-1}$ & $0.286 \mathrm{~ns}$ \\
\hline 16. Plant height vs tillers plant ${ }^{-1}$ & $-0.268 \mathrm{~ns}$ \\
\hline 17. Plant height vs spike length & $0.161 \mathrm{~ns}$ \\
\hline 18. Plant height vs spikelets spike ${ }^{-1}$ & $-0.048 \mathrm{~ns}$ \\
\hline 19. Plant height vs grains spike - $^{-1}$ & $0.130 \mathrm{~ns}$ \\
\hline 20. Plant height vs seed index & $-0.726^{*}$ \\
\hline 21. Plant height vs grains yield plant ${ }^{-1}$ & $0.083 \mathrm{~ns}$ \\
\hline 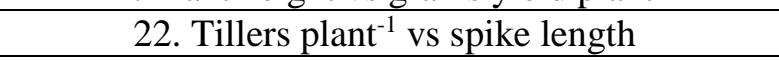 & $0.561 \mathrm{~ns}$ \\
\hline 23. Tillers plant-1 vs spikelets spike-1 & $0.536 \mathrm{~ns}$ \\
\hline 24. Tillers plant ${ }^{-1}$ vs grains spike ${ }^{-1}$ & $0.583 \mathrm{~ns}$ \\
\hline 25. Tillers plant ${ }^{-1}$ vs seed index & $0.783 * *$ \\
\hline 26. Tillers plant ${ }^{-1}$ vs grains yield plant $^{-1}$ & $0.820 * *$ \\
\hline 27. Spike length vs spikelets spike ${ }^{-1}$ & $0.764 * *$ \\
\hline 28. Spike length vs grains spike ${ }^{-1}$ & $0.746^{* *}$ \\
\hline 29. Spike length vs seed index & $0.722^{*}$ \\
\hline 30. Spike length vs grains yield plant ${ }^{-1}$ & $10.873 * *$ \\
\hline 31. Spikelets spike ${ }^{-1}$ vs grains spike ${ }^{-1}$ & $0.852 *$ \\
\hline 32. Spikelets spike ${ }^{-1}$ vs seed index & $0.715^{* *}$ \\
\hline 33. Spikelets spike ${ }^{-1}$ vs grains yield plant ${ }^{-1}$ & $0.813^{*}$ \\
\hline 34. Grains spike ${ }^{-1}$ vsseed index & $-0.976 * *$ \\
\hline 35. Grains spike ${ }^{-1}$ vs grains yield plant ${ }^{-1}$ & $0.987 * *$ \\
\hline 36. Seed index vs grains yield plant ${ }^{-1}$ & $0.733^{*}$ \\
\hline
\end{tabular}

$=$ Significant at 0.01 level of probability

$* *=$ Significant at 0.05 level of probability

ns $=$ Non-significant

\section{Discussion}

Since the coefficient correlation observed that association among independent variables and linear relation degree between variables [10]. That is why indirect as well as direct influence between yield and different yield factors must be aware by the breeding strategies [11]. Because of this purpose coefficient path analysis is perfomed for expressing the various amount of indirect as well direct influence of traits which are interrelated by the results of traits such as yield grain [12]. Variation in one finding showed proportional change in another results and it may be due to positive and negative. The positively and high results of correlation indicates that increase in one traits will results in the improvement or we can say also increase in the other related trait. Whereas the negative 
findings of correlation showed that increase in one trait will be cause in the decrease of their linked traits. The maturity of crop at early age can be helpful for crop of able it for double pattern of cropping on the double type growing regions of Pakistan, that may be able wheat crop to producer during the better moisture, without losing by delay season effect as well as insect and pest damages. This also reduced the pesticide and chemical uses through different other sources such as fertilizer and irrigation water applications due to now water shortage is a serious problem in Pakistan. Hence though reduction in the maturity time of crop we can protect the water of irrigation for further requirement of crop.

\section{Analysis of path coefficient}

Analysis of path coefficient showed a prominent view for sharing various components of yield to all genotypes of yield of grain in our research. This method indicates a productive and effect way to find out direct as well as indirect sources of correlation. The effect of these different component may be direct or indirect observed that contribution and percentage of grain yield displayed in Table-3. Various components of yield of such as tillers of plant-1, grain spike numbers, plant height, index of seed 1000 grains weight and spikes spikelet's were called independent variable and the analysis of path was this way to observed the influence and input percentage of these different components on the yield of plant- 1 that is a dependent variable. Path of analysis coefficient measures direct effect of one variable on another, and permits separation of correlation coefficients into various components of direct and indirect influences. Portioning of total correlation into the direct and indirect effects provides the actual information on contribution of various characters and therefore for the selection to improve the yield. Due to these positive and negative results of correlation between 2 variables $r$ traits is highly valuable. Days $75 \%$ heading character to $75 \%$ days maturity was observed highly influenced directly on the yield of grain plant than height of plant, whereas it was observed highly negative influenced in plant yield grain, by plant tillers. The $75 \%$ maturity days showed higher negative indirect influence on yield of grain plant than by length of spike, whereas finding showed that higher direct influence on the plant grain yield on the index of seed.

The analysis of coefficient path for plant-1 yield grain showed that different traits such as seed index and spikes-1 $\mathrm{f}$ grain showed higher and positive direct influence on the yield of seed Tabel_3. The positive and higher effect of spike-1 grain as well as seed index was observed due to its significant and positive relation with plant-1 seed yield. Due to this it is said that little bit enhance in above one character that might share directly to the yield of seed. Same statement described by $[13,14]$.

Plant height trait was observed highly positive indirect effect on the plant yield grain by means of tillers plant numbers than the spike of spikelet's and length of spike1 , instead index of seed and spike of grains showed negatively direct influence. By consideration on the tillers plant number trait was found high positive indirect effect on the spike of grain than high of plant, index of seed and spikes of spikelet's, while the length of spike showed a relatively lower negative results of indirect effect on the yield of grain plant-1. The traits length of spike showed higher indirect effect on yield of grain plant-1, though spikes of grain and index of seed, hence the tillers plant number showed negatively indirect influence. Days $75 \%$ heading character to $75 \%$ days maturity was observed highly influenced directly on the yield of grain plant than height of plant, whereas it was observed highly negative influenced in plant yield grain, by plant tillers. The $75 \%$ maturity days showed higher negative indirect influence on yield of grain plant than by length of spike, whereas finding showed that higher direct influence on the plant grain yield on the index of seed. The spike of spikelet's number trait showed 
positively indirect influence on the plant grain yield by spike grains than height of plant and index of seed, whereas the plant tillers number was observed negatively affect indirect. The results of spike of grain, showed positive and high influence on the plant grain yield, length of spikes and index of seed, whereas it was observed highly positive in plant grain yield by length of spike and index of seed, while the tiller plant numbers was found negative indirect influence. Index of seed trait showed highly positive and negatively higher influence on plant grain yield by plant tillers and spike grains. [15], calculated analysis of correlation coefficient of path among the grain yield and various components of yield of different genotypes of 20 wheat. Positively and significant correlation results was found among the plant yield and density of plant, plant height, grain weight spike and spike number of grain. The yield of grain was found negatively significant correlation with the heading days. The results of correlation direct positive influence on the weight of spike grain and plant height and negatively direct effect on the days heading among significant association of grain of yield found that mention various traits of yield may be superior selection tool for improving the yield genotypes.

\section{Conclusion}

It was concluded that Analysis of path coefficient showed the direct effect of grain plant $^{-1}$ yield was quickly found by the spikep $^{-1}$ grains 0.8320 followed by index of seed, whereas the result of spikelet's spike ${ }^{-}$ ${ }^{1}$ was observed positively influence on the yield of grain. In controversial the highest negatively influence was observed by plant ${ }^{-}$ 1 tillers number 0.3702 , followed by the height of plant 0.836 and length of spike 0.3813 that is why, direction genotypes selection for the yield of grain because of spikelet's spike ${ }^{-1}$, index of seed and grains of spike ${ }^{-1}$.

\section{Authors' contributions}

Conceived and designed the experiments: AA Rajper \& SK Baloch, Performed the experiments: RR Kaleri, $\mathrm{K}$ Baloch, $\mathrm{S}$ Ahmed \& AA Kaleri, Analyzed the data: AL Leghari, SH Kaleri \& JK Soothar, Wrote the paper: RR Kaleri \& SR Soomro.

\section{References}

1. Hanson HN, Borlaug E \& Anderson RG (1982). Wheat in the third world. Boulder, Colorado USA. pp. 13.

2. Mary SS \& Gopalan A (2006). Dissection of genetic attributes yield traits of fodder cowpea in F3 and F4. $J$ of Applied Sci Res 2: 805-808.

3. Yagdi K (2009). Path coefficient analysis of some yield components in durum wheat (Tiiticum durumDesf). Pak $J$ of Bot 41(2): 745-751.

4. Ali MA, Nawab NN, Rasool GR \& Saleem M (2008). Estimates of variability and correlations for quantitative traits in Cicer arietinum L". J Agric Social Sci 4(4): 177-179.

5. Khaliq I, Parveen N \& Chowdhry MA (2004). Correlation and path coefficient analysis in bread wheat. Int. J Agric Biol 6: 633-635.

6. Yasin AB \& Singh S (2010). Correlation and path coefficient analyses in sunflower. J. Plant Breed and Crop Sci 2(5): 129-133.

7. Steel RGD \& Torrie JH (1980). Principles and Procedures of Statistics. (With special Reference to the Biological Sciences). McGraw-Hill Book Company, New York, Toronto, London.

8. Snedecor GW \& Cochran WG (1959). Statistical methods". Press. Iowa, pp. 507.

9. Dewey DR \& Lu KH. (1959). A Correlation and path coefficient analysis of components of crested wheat grass seed production. Agron J 51: 515-518.

10. Dokuyucu TA, Akkaya M \& Akcura (2002). Path analysis of yield related traits of Durum wheat genotypes grown in rainfed conditions of Mediterranean Region. Turk. J Field Crops 7 (1): 31-39.

11. Turk M \& Celik N (2006). Correlation and path coefficient analysis of seed 
yield components in the Sainfoin. $J$ Biol Sci 6: 758-762.

12. Kara B \& Akman Z (2007). Correlation and path coefficient analysis in the local wheat genotypes. Süleyman Demirel Üniversitesi Fen Bilimleri Enstitüsü Dergisi 11 (3): 219-224.

13. Meyari S, Nouri F, Sasani F, Nazafian G \& Aghayari F (2013). Correlation and path analysis of grain yield and its components of some bread wheat (Triticum aestivem L.) under normal and source restriction conditions. Int. J. Farming and Allied Sci 2(23): 10651069.
14. Shahryari R, Eshghi AG, Mollasadeghi \& Serajamani R (2013). Separating correlation coefficients into direct and indirect effects of important morphological traits on grain yield in 28 bread wheat genotypes under terminal drought stress. Int J Farming and Allied Sci 2(24): 1210-1216.

15. Mehmet A \& Yildirim T (2006). "Path coefficient analysis of yield and yield components in bread wheat (Triticum aestivum L.) Genotypes". Pak J Bot 38(2): 417-424. 